Indonesian Journal of Islamic Psychology

Volume 1. Number 1, Juni 2019. (p-ISSN: 2685-1482)

website: http://e-journal.iainsalatiga.ac.id/index.php/ijip/index

\title{
Apakah Demografi Memprediksi Ketidakjujuran Akademik?
}

\author{
Herdian, Dyah astorini wulandari, dan Istianah \\ Universitas Muhammadiyah Purwokerto, Indonesia \\ herdianump@gmail.com
}

\begin{abstract}
This study aimed at examining academic behavior and its relation to demography. The quantitative descriptive approach was used to study more broadly with data collection tools using a closed questionnaire. Respondents in this study were 96 students of the Faculty of Economics and Business at X College in Purwokerto. The results of the study show that, in each semester, honest behavior was more than honest behavior, especially in the first semester of the lecture. While the gender of both women and men did not have high differences. Academic dishonesty was also related to the origin of school, general schools (not based on religion) were more compared to religious-based schools such as MAN. Whereas based on age, 18-20 more academic dishonesty was found.
\end{abstract}

Keyword: academic dishonesty; honesty; student college

\begin{abstract}
Abstrak
Penelitian ini mengkaji perilaku akademik dan kaitannya dengan demografi. Pendekatan kuantitatif deskriptif digunakan untuk mengkaji lebih luas dengan alat pengumpulan data menggunakan kuesioner tertutup. Responden dalam penelitian ini yaitu 96 mahasiswa Fakultas Ekonomi dan Bisnis pada Perguruan Tinggi X di Purwokerto. Hasil penelitian menunjukan bahwa, disetiap semester perilaku tidak jujur lebih banyak dibandingkan perilaku jujur, terutama pada semester awal perkuliahan. Sedangkan jenis kelamin baik perempuan maupuun laki-laki tidak memiliki perbedaan yang tinggi. Ketidakjujuran akademik juga berkaitan dengan asal sekolah, sekolah yang umum (tidak berbasis agama) lebih banyak dibandingkan dengan sekolah yang berbasis agama seperti MAN. Sedangkan berdasarkan usia, 18-20 lebih banyak ditemukan ketidakjujuran akademik.
\end{abstract}

Kata Kunci: ketidakjujuran akademik; kejujuran; mahasiswa 


\section{Pendahuluan}

Ketidakjujuran akademik hingga saat ini masih menjadi salah satu isu penelitian yang banyak dilakukan di berbagai Negara. Berbagai penelitian ketidakjujuran akademik telah dikaji di Negara China (Bernardi, dkk, 2008), Thailand (Thomas, 2017), Singapura (Lim \& See, 2001), Inggris (Park, 2003), Swedia (Trost, 2009), hongkong (Chapman \& Lupton, 2014) Jerman (Sattler, Graeff, \& Willen, 2013), Rumania (Teodorescu \& Andrei, 2009), Malaysia (Imran \& Nordin, 2013), Selandia Baru (Kuntz \& Butler, 2014), Taiwan (Lin \& Wen, 2007) dan beberapa Negara di bagian Eropa, Amerika, dan Afrika (Pupovac, Bilic-Zulle \& Petrovecki, 2008; Vasconcelos, Leta, and Costa; 2009).

Di Indonesia sendiri telah banyak penelitian dengan tema ketidakjujuran akademik. Beragam investigasi mulai dari jenjang pendidikan, hingga pada faktor yang menyababkan ketidakjujuran akademik terjadi. Pada jenjang pendidikan misalnya, ketidakjujuran akademik telah dilakukan pada pendidikan Sekolah Dasar (Fredrika, 2013), Sekolah Menengah Pertama (Lestari \& Asyanti, 2015), Sekolah Menengah Atas (Ungusari, 2015) dan Peguruan Tinggi (Herdian \& Wulandari, 2018). Sedangkan penelitian yang mengkaji faktor ketidakjujuran akademik dilakukan oleh banyak penelitian (lihat Handayani \& Baridwan, 2013: Nursani \& Irianto; 2013; Mujahidah; 2009).

Mengacu pada pengertian ketidakjujuran akademik atau yang sering dikenal dengan istilah academic dishonesty, academic cheating, academic misconduct sebagai bentuk perilaku tidak jujur dalam setting pendidikan. Beberapa tokoh memberikan definisi yang berbeda-beda namun masih pada makna yang sama, Kibler (1993) mengartikan ketidakjujuran akademik merupakan kecurangan dan plagiarism yang 
terjadi pada siswa, baik dalam bentuk memberi atau pun menerima bantuan yang tidak sah dalam latihan akademis. Kajian lain mengatakan bahwa ketidakjujuran akademik ialah suatu tindakan pelanggaran norma, nilai, aturan sosial yang berkaitan dengan karya ilmiah akademik di lingkungan pendidikan (Etter, Cramer, \& Finn, 2006; Jones, 2011; Thomas \& Sassi, 2011).

Penelitian ketidakjujuran akademik menjadi menarik karena merupakan salah satu bentuk investigasi dari permasalahan yang berkaitan dengan gagalnya pendidikan karakter. Karakter yang seharusnya terinternalisasi adalah nilai kejujuran. Namun faktanya nilai kejujuran tidak dapat diaplikasikan baik dalam kehidupan di luar sekolah maupun dalam kehidupan sekolah dalam hal ini sebagi akademisi. Sebagai contoh, hasil studi pendahuluan yang dilakukan pada salah satu universitas X di Jawa Tengah, informasi diperoleh melalui wawancara dengan salah satu staf pengajar di fakultas ekonomi dan bisnis. Informasi tersebut mengatakan bahwa mahasiswa sudah makin berani mencontek dalam ujian di kelas maupun di luar kelas, seperti tugas. Informasi lainya diperoleh bahwa pengajar sangat menyayangkan sekali perilaku ketidakjujuran akademik dilakukan oleh mahasiswa yang notabene lulusanya akan kerja di perbankan. Hal tersebut diyakini sebagai bentuk awal perilaku korupsi yang kemungkinan akan terjadi didalam dunia kerjanya kelak.

Berdasarkan studi pendahuluan di atas, ketidakjujuran dikatakan sebagai salah satu karakter yang negatif yang tidak menutup kemungkinan akan menjadi kebiasaan dan dibawa pada lingkungan kerja nantinya. Oleh sebab itu penelitian ketidakjujuran akademik pada mahasiswa fakultas ekonomi dan bisnis penting dikaji untuk dapat 
dideskripsikan bagaimana perilaku tidak jujur tersebut dilakukan dalam dunia akademik.

Hal yang menarik selain bagaimana perilaku tidak jujur terjadi, yaitu faktor lainnya yang kemungkinan dapat menjadi temuan lain dari penelitian ini seperti unsur demografi. Beberapa hasil penelitian mengatakan bahwa ketidakjujuran sangat ditentukan oleh Jenis kelamin, dimana laki-laki lebih banyak dilakukan melakukan ketidakjujuran akademik dibandingkan dengan perempuan (Whitley, 1998; Diekhof, 1996; Jensen, 2001; Hendricks, 2004; Roig, 2005; Hensley dkk, 2013). Faktor demografi lainya menarik untuk diteliti lebih luas sehingga dapat memperkaya keilmuan dalam tema penelitian ketidakjujuran akademik.

Berdasarkan paparan di atas, permasalahan muncul ketika adanya perilaku yang sudah membudaya dilingkungan akademik akan berdampak pada perilakunya kelak dilingkungan kerja. Sehingga perlu adanya kajian ketidakjujuran akademik dilingkungan mahasiswa

\section{Ketidakjujuran Akademik}

Jauh hari Bowers (1964) mendefinisikan ketidakjujuran akademik sebagai "siswa terlibat dalam perilaku tidak jujur tidak terbatas pada kegiatan seperti menjiplak dan menyontek". Moeck (2002) ketidakjujuran akademik adalah penyalahgunaan materi akademik dengan menghancurkan atau mengubah bagian-bagian konten. Selaras dengan Guthrie (2009) mengatakan bahwa ketidakjujuran yaitu sebagai perilaku akademik yang tidak sesuai dengan persyaratan penilaian dan kebijakan kelembagaan; dimana siswa berperilaku dengan cara yang dimaksudkan untuk mendapatkan keuntungan yang tidak semestinya kaitannya dengan penilaian mereka. Sagoro (2013) yang mengemukakan 
bahwa kecurangan akademik adalah perbuatan tidak jujur dan melanggar peraturan yang dilakukan untuk mencapai tujuan tertentu.

Cizek (2003) memberikan batasan dalam mendefinisikan ketidakjujuran akademik. Perilaku ketidakjujuran akademik meliputi tiga kategori: (1) memberi, menerima, atau menerima informasi, (2), menggunakan bahan terlarang, dan (3) memanfaatkan kelemahan orang, prosedur, atau proses untuk mendapatkan keuntungan pada pekerjaan akademis. Deifinisi ini memberikan gambaran yang lebih jelas mengenai batasan ketidakjujuran akademik dibandingkan dengan definisi lainya.

Ketidakjujuran akademik disebabkan oleh banyak factor diantaranya yaitu (1) karena tekanan dari keluarga (Arinda, 2015), keluarga adalah sekelompok orang yang memberikan standar norma yang berlaku dalam keluarga. Standar tersbut yang berwujud dalam bentuk ekspektasi yang diinginkan terkadang tidak sesuai dengan kenyataan sehingga akan membuat individu menjadi tertekan jika hal tersebut tidak sesuai dengan apa yang diinginkan. (2) tekanan dari teman (Mujahidah, 2009) dan persahabatan atau friendship (Griebeler, 2017), beberapa hasil penelitian melaporkan bahwa ketidakjujuran sangat dipengaruhi oleh tekanan dari lingkungan sekitar salah satunya adalah teman. Persahabatan yang lebih dekat meningkatkan kemungkinan kecurangan akademik terutama pada siswa yang memiliki nilai rendah (Griebeler, 2017). (3) Norma Subjektif (Lawson, 2004), Sebagaimana yang kita ketahui bahwa persepsi individu terkait dengan tekanan sosial untuk melakukan ataupun tidak melakukan perilaku. hal ini terjadi dimana siswa memandang kepraktisan atau perilaku curang dingggap sebagai suatu tindakan sebagai lebih penting daripada mengikuti norma dan etika yang berlaku. (4) Kemajuan teknologi, (Mirza \& Staples, 2010) Semakin berkembang teknologi, maka semakin 
memudahkan akademisi untuk dapat mencari literature melalui dunia maya. Kemajuan teknologi tidak digunakan sebagaimana mestinya sesuai dengan etika yang ada. Sehingga banyak siswa memanfaatkan teknologi untuk melakukan ketidakjujuran akademik dalam menyelesaikan tugasnya.

Istilah ketidakjujuran akademik dikenal pula dengan istilah plagiarisme. Murphy dan Banas (2009) menjabarkan bentuk perilaku dari plagiarisme meliputi; (1) Membeli atau menyalin pekerjaan orang lain (seperti makalah) dan mengkalim sebagai hasil kerja sendiri, (2) Menyalin dari kertas orang lain selama kuis atau ujian, (3) Membayar orang lain untuk mengerjakan tugas sekolah sendiri. Bentuk lain dari ketidakjujuran akademik yaitu mengerjakan pekerjaan lain, mengubah nilai atau catatan akademis melalui pemalsuan, mencuri atau merusak properti milik sekolah, berbohong atau melebih- lebihkan data untuk membuat hasil dari pekerjaan anda tampak lebih dipercaya, dan kecurangan pada tes atau tugas lainnya dengan menggunakan catatan atau sumber lainnya yang tidak seharusnya digunakan.

\section{Metodologi Penelitian}

Penelitian ini menggunakan pendekatan kuantitatif deskriptif dengan alat pengumpulan data menggunakan kuesioner tertutup. Responden dalam penelitian ini yaitu 96 mahasiswa Fakultas Ekonomi dan Bisnis pada Perguruan Tinggi X di Purwokerto. Proses Analisis data menggunakan data yang direspon kemudian dikategorisasikan berdasarkan prosentase dan disesuaikan dengan persamaan tema, lalu frekuensi respon dalam kelompok kategorinya ditabulasi silang dengan demografi responden. 
Herdian, Dyah astorini wulandari, dan Istianah

\section{Hasil Penelitian dan Pembahasan}

Berdasarkan hasil penelitian ini, dipaparkan sebelumnya terkait profile informan yang berkaitan dengan demografi yaitu jenis kelamin, semester, usia dan asal sekolah. Berikut dipaparkan lebih rinci.

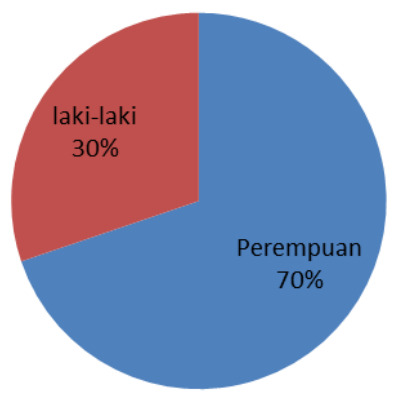

gambar 1. profil responden berdasarkan jenis kelamin

Berdasarkan gambar 1 profil responden berdasarkan jenis kelamin, responden berjeniskelamin prempuan mendominasi dalam penelitian ini yaitu sejumlah $70 \%$ atau 67 mahasiswa. Sedangka responden berjenis kelamin laki-laki yaitu sejumlah 30\% atau 29 mahasiswa.

Tabel 1. Profil responden berdasarkan semester, usia dan asal sekolah

\begin{tabular}{cccccc}
\hline semester & Jumlah & usia & jumlah & Asal sekolah & jumlah \\
\hline 2 & 47 & 18 & 20 & MAN & 11 \\
4 & 11 & 19 & 26 & SMA & 59 \\
6 & 35 & 20 & 29 & SMK & 26 \\
8 & 3 & 21 & 14 & & \\
& & 22 & 6 & & \\
& & 23 & 1 & & \\
N & 96 & N & 96 & N & 96 \\
\hline
\end{tabular}

Berdasarkan tabel 1. Responden semester 2 mendominasi penelitian ini yaitu sejumlah 47 mahasiswa, diikuti semester 6 sejumlah 35 mahasisswa, semester 4 sejumlah 11 mahasiswa dan responden 
Herdian, Dyah astorini wulandari, dan Istianah

semester 8 jumlahnya paling sedikit yaitu 3 mahasiswa. Paparan profil responden berdasarkan usia, responden dalam penelitian ini berusia 18 hingga 23 tahun. Responden dengan usia 18-20 tahun merupakan responden terbanyak yaitu sejumlah 75 mahasiswa dan responden dengan usia 23 tahun merupakan responden paling sedikit yaitu sejumlah 1 mahasiswa. Paparan lain berdasarkan tabel 1 yaitu asal sekolah. Pada penelitian ini asal sekolah dikategorikan berdasarkan 3 jenis sekolah, yaitu MAN (madrasah aliyah negeri) sejumlah 11 mahasiswa, SMA (Sekolah menengah atas) sejumlah 59 mahasiswa dan SMK (sekolah menengah kejuruan) sejumlah 26 mahasiswa. Berdasarkan kategori sekolah tersebut, responden yang merupakan alumni dari SMA mendominasi penelitian ini.

Tabel 2. Jumlah perilaku jujur dan tidak jujur berdasarkan semester

\begin{tabular}{cccccc}
\hline \multirow{2}{*}{ semester } & \multicolumn{5}{c}{ Perilaku } \\
\cline { 2 - 6 } & Tidak jujur & $\%$ & jujur & $\%$ & jumlah \\
\hline 2 & 36 & 76.6 & 11 & 23.4 & 47 \\
4 & 10 & 90.9 & 1 & 9.1 & 11 \\
6 & 32 & 94.1 & 2 & 5.9 & 34 \\
8 & 1 & 33.3 & 2 & 66.7 & 3 \\
total & $\mathbf{7 9}$ & $\mathbf{8 3 . 2}$ & $\mathbf{1 6}$ & $\mathbf{1 6 . 8}$ & $\mathbf{9 5}$ \\
& \multicolumn{5}{c}{ tanpa keterangan } \\
\hline
\end{tabular}

Berdasarkan hasil penelitian, perilaku jujur dan tidakjujur dalam akademik dipaparkan terlebih dahulu untuk melihat berapa banyak prosentase perilaku tersebut terjadi. pada tabel 2 dipaparkan bahwa jumlah responden berperilaku tidak jujur sebanyak 79 mahasiswa atau 83,2\% sedangkan jumlah responden berperilaku jujur sebanyak 16 mahasiswa atau 16,8\%. Terdapat 1 responden yang tidak memberikan keterangan terkait perilaku jujur atau tidak jujur sehingga pada tabel berikutnya 1 responden tidak dibahas pada analisis. 
Tabel 3. Perilaku akademik berdasarkan jenis kelamin

\begin{tabular}{cccccc}
\hline jenis & \multicolumn{5}{c}{ Perilaku } \\
\cline { 2 - 5 } kelamin & Tidak Jujur & $\%$ & Jujur & $\%$ & \\
\hline Laki-laki & 24 & 85.7 & 4 & 14.3 & 28 \\
Perempuan & 55 & 82.1 & 12 & 17.9 & 67 \\
Total & $\mathbf{7 9}$ & $\mathbf{8 3 . 2}$ & $\mathbf{1 6}$ & $\mathbf{1 6 . 8}$ & $\mathbf{9 5}$ \\
\hline
\end{tabular}

Pada tabel 3 dipaparkan jumlah responden jenis kelamin laki-laki dan perempuan tidak seimbang jika dibandingkan. Responden laki-laki sejumlah $85.7 \%$ berperilaku tidakjujur dan responden perempua berjumlah $82.2 \%$ berperilaku tidak jujur. Hal ini tidak menunjukan perbedaan yang begitu signifikan pada responden jenis kelamin diantara laki-laki atau perempuan. Namun, penelitian terdahulu yang dilakukan oleh Whitley (1998), Diekhof (1996), Jensen (2001), Hendricks (2004), Roig (2005) dan Hensley dkk (2013) mengatakan bahwa jenis kelamin laki-laki lebih banyak dilaporkan melakukan ketidakjujuran akademik dibandingkan dengan perempuan. Hal ini menunjukan bahwa saat ini perilaku ketidakjujuran tidak ditentukan oleh jenis kelamin.

Tabel 4. Perilaku akademik berdasarkan usia

\begin{tabular}{cccccc}
\hline \multirow{2}{*}{ Usia } & \multicolumn{5}{c}{ Perilaku } \\
\cline { 2 - 5 } & jujur & $\%$ & tidak jujur & $\%$ & jumlah \\
\hline 18 & 5 & 25.0 & 15 & 75.0 & 20 \\
19 & 5 & 19.2 & 21 & 80.8 & 26 \\
20 & 4 & 14.3 & 24 & 85.7 & 28 \\
21 & 2 & 14.3 & 12 & 85.7 & 14 \\
22 & 0 & 0.0 & 6 & 100.0 & 6 \\
23 & 0 & 0.0 & 1 & 100.0 & 1 \\
total & $\mathbf{1 6}$ & $\mathbf{1 6 . 8}$ & $\mathbf{7 9}$ & $\mathbf{8 3 . 2}$ & $\mathbf{9 5}$ \\
\hline
\end{tabular}


Pada tabel 4. Prosentase perbandingkan perilaku jujur dan tidakjujur dilingkung usianya masing-masing. Perilaku ketidakjujuran akademik jika dilihat dari usia, perilaku tidakjujur usia 18 lebih sedikit dibandingkan perilaku tidakjujur diusia 19-21 tahun. Hal ini dapat diartikan bahwa semakin bertambah usia seseorang maka semakin naik ketidakjujuran akademiknya dikampus. Namun, hal ini masih perlu dikaji lebih lanjut. Melihat responden dalam penelitian ini tidak melibatkan banyak responden. Tabel 4. Juga memaparkan usia 22 dan 23 sebagai responden dengan jumlah paling sedikit. Responden dengan Usia 22 tahun yang berjumlah 6 mahasiswa, semuanya menunjukan perilaku tidak jujur. Sedangkan usia 23 berperilaku tidakjujur dengan jumlah responden 1 mahasiswa. Penelitian sebelumnya tidak banyak yang mengkaji bagaimana usia memiliki hubungan dengan ketidakjujuran akademik. Pada dasarnya pengalaman membuat individu akan kaya dengan memori tentang perilaku-perilaku yang tampak disekitarnya. Sehingga sangat dimungkinkan bahwa perilaku akan bertambah jujur atau bahkan berkurang. Namun temuan dalam penelitian ini adalah tingginya usia individu ada hubungannya dengan bertambahnya perilaku ketidakjujuran akademik. Tentu hal ini perlu dikaji lebih dalam karena banyak faktor yang menyebabkan individu mempertahankan perilaku ketidakjujuran akademik terutama lingkungannya (Thomas \& Sassi, 2011).

Tabel 5. Perilaku akademik berdasarkan asal sekolah

\begin{tabular}{cccccc}
\hline \multirow{2}{*}{ Sekolah } & \multicolumn{5}{c}{ Perilaku } \\
\cline { 2 - 5 } MAN & jujur & $\%$ & tidak jujur & $\%$ & \\
\cline { 2 - 5 } SMA & 4 & 33.3 & 8 & 66.7 & 12 \\
SMK & 8 & 13.8 & 50 & 86.2 & 58 \\
total & 4 & 16.0 & 21 & 84.0 & 25 \\
\hline
\end{tabular}


Pada tabel 5. Menjelaskan bahwa jumlah partsipan terbanyak berasal dari SMA yaitu 58 mahasiswa, selanjutnya responden dari SMK berjumlah 25 mahasiswa dan MAN berjumlah 12 mahasiswa. Meskipun jumlahnya tidak proporsional jika dibandingkan berdasarkan sekolah, perilaku ketidakjujuran akademik pada jenjang SMA terbanyak dilakukan dengan jumlah 86.2\%. Sedangkan perilaku tidakjujur pada SMK berjumlah 84\% dan MAN sejumlah 66.7\%. Umumnya seseorang akan membawa perilaku akademiknya dari jenjang sebelumnya ke jenjang berikutnya. Hal tersebut dilaporkan dalam penelitian Herdian (2017) bahwa perilaku ketidakjujuran akademik yang dilakukan pada jenjang Sekolah Menengan Atas (SMA) telah dilakukan terlebih dahulu pertamakali di jenjang pendidikan Sekolah Dasar (SD). Penelitian ini menyoroti perilaku tidakjujur yang dilakukan oleh mahasiswa bahwa faktanya menjunjukan perilaku tersebut pernah dilakukan pada jenjang pendidikan Sekolah menengah atas.

\section{Simpulan}

Kajian ini menyimpulkan bahwa perilaku ketidakjujuran akademik pada setiap semester lebih banyak ditemukan dibandingkan perilaku jujur, terutama pada semester awal perkuliahan. Berdasarkan jenis kelamin tidak memiliki perbedaan yang tinggi, baik perempuan maupun laki-laki. Ketidakjujuran akademik juga berkaitan dengan asal sekolah, sekolah yang umum (tidak berbasis agama) lebih banyak dibandingkan dengan sekolah yang berbasis agama seperti MAN. Sedangkan usia 18-20 secara berrutan lebih banyakditemukan perilaku ketidakjujuran akademik. 
Penelitian ini memiliki banyak kekurangan yang akan menjadi bahan pertimbangan riset bagi penelitian selanjutnya. Diantaranya adalah proporsi dari responden dan sedikitnya responden. Sehingga untuk penelitian mendatang dapat menggunakan banyak responden dengan proporsi demografi yang sama. Penelitian ini juga dapat menjadi kebijakan dari kampus terkait perilaku ketidakjujuran akademik. intervensi lebih dini diharapkan dapat berpengaruh terhadap ketidakjujuran akademik selanjutnya.

\section{DaftarPustaka}

Arinda, F. P. 2015. Ketidakjujuran Akademik Mahasiswa Perguruan Tinggi X di Surakarta skripsi (tidak diterbtkan). Universitas Muhammadiyah Surakarta.

Bernardi, R. A., Baca, A. V., Landers, K. S., \& Witek, M. B. 2008. Methods of cheating and deterrents to classroom cheating: An international study. Ethics \& Behavior, 18 (4), 373-391.

Bowers, W. J. 1964. Student Dishonesty and It's Control in College. New York: Columbia University Press.

Chapman, K. J., \& Lupton, R. A. 2004. Academic dishonesty in a global educational market: A comparison of Hong Kong and American university business students. International Journal of Educational Management, 18(7), 425-435.

Cizek, G. J. 2003. Detecting and preventing classroom cheating: Promoting integrity in assessment. Corwin Press.

Etter, S., Cramer, J. J., \& Finn, S. 2006. Origins of academic dishonesty: Ethical orientations and personality factors associated with attitudes about cheating with information technology. Journal of Research on Technology in Education, 39 (2), 133-155. 
Fredrika, M. E., \& Prasetyawati, W. 2013. Gambaran kecurangan Akademik pada Siswa Kelas 6 Sekolah Dasar. Skripsi (tidak diterbitkan) Jakarta Fakultas Psikologi Universitas Indonesia.

Griebeler, M. D. C. (2017). Friendship And In-Class Academic Dishonesty. Economics Letter Journal s, 150, 1-3.

Guthrie, C. L. 2009. Plagiarism and cheating: a mixed methods study of student academic dishonesty. Thesis Master of Social Sciences, New Zealand, The University of Waikato

Handayani \& Baridwan. 2013. Faktor-faktor yang mempengaruhi perilaku ketidakjujuran akademik: modifikasi theory of planed behaviour. Jurnal Ilmiah Mahasiswa FEB, 2 (1) dipetik Agustus 3, 2015

dari http://portalgaruda.org/?ref=browse $\&$ mod=viewarticle $\&$ article $=1$ $\underline{89226}$

Hensley, L. C., Kirkpatrick, K. M., \& Burgoon, J. M. 2013. Relation of gender, course enrollment, and grades to distinct forms of academic dishonesty. Teaching in Higher Education, 18 (8), 895907.

Herdian \& Lestari, S. 2016. Apakah Calon Pendidik Jujur Saat Mengerjakan Ujian Akhir Semester? Tesis (tidak diterbitkan). Universitas Muhammadiyah Surakarta.

Herdian, H., \& Wulandari, D. A. 2018. Ketidakjujuran Akademik pada Calon Guru Agama. Psikologia: Jurnal Psikologi, 2 (1), 1-16.

Herdian, H., 2017. Ketidakjujuran Akademik Pada Saat UNBK Tahun 2017. Jurnal Psikologi Jambi, 2 (2), 1-9 Https://OnlineLournal.Unja.Ac.Id/Index.Php/Ipj/Article/View/4790

Hendricks, B. 2004. Academic Dishonesty: A Study in The Magnitude of and Justification forAcademic Dishonesty Among College 
Undergraduate and Graduate Students. Journal of College Student Development (35): 212-260

Imran, A. M., \& Nordin, M. S. 2013. Predicting the underlying factors of academic dishonesty among undergraduates in public universities: a path analysis approach. Journal of Academic Ethics, 11(2), 103120.

Jensen, L, A., Arnett, J. J., Feldman, S. S., \& Cauffman, E. 2002. It's Wrong, But EverybodyDoes It: Academic Dishonesty Among High School And College Students.Contemporary Educational Psychology 27, 209-228.

Jones, D. L. R. 2011a. Academic dishonesty: are more students cheating? Business Communication Quarterly, 74 (2), 141-150.

Kibler, W. L. 1993. Academic Dishonesty: A Student Development Dilemma. Naspa Journal. 30. 253-262.

Kuntz, J. R. C., \& Butler, C. 2014. Exploring individual and contextual antecedents of attitudes toward the acceptabilityof cheating and plagiarism. Ethics \& Behavior, 24, 478-494. doi:10.1080/10508422.2014.908380

Lawson. 2004. Is classroom cheating related to business students propensity to cheat in the real world? Journal of Business Ethics, 49:189-199.

Lestari, S., \& Asyanti, S. 2015. Apakah siswa SMP berperilaku jujur dalam situasi ulangan? The 2nd University Research Coloquium 2015 ISSN 2407-9189.

Lim, V. K., \& See, S. K. 2001. Attitudes toward, and intentions to report, academic cheating among students in Singapore. Ethics \& Behavior, 11 (3), 261-274. 
Lin, C. H. S., \& Wen, L. Y. M. 2007. Academic dishonesty in higher educationa nationwide study in Taiwan. Higher Education, 54(1), 85-97.

Mirza, N., \& Staples, E. 2010. Webcam as a new invigilation method: students' comfort and potential for cheating. The Journal of Nursing Education, 49 (2), 116-9. doi:10.3928/0148483420090916-06.

Moeck, P. G. 2002. Academic Dishonesty: Cheating among Community College Students. Community College Journal of Research and Practice, 26, 479-491

Mujahidah 2009. Perilaku menyontek laki-laki dan perempuan Studi Meta Analisisis. Jurnal Psikologi, 2 (2), 177-199.

Murphy, M.M., \& Banas, S. L. 2009. Character Education Overcoming Prejudice. New york: Chelsea House publisher

Nursani, R., \& Irianto, G. 2013. Perilaku Kecurangan Akademik Mahasiswa: Dimensi Fraud Diamond. Jurnal Ilmiah Mahasiswa FEB, 2 (2).

Park, C. 2003. In other (people's) words: Plagiarism by university students-Literature and lessons. Assessment \& Evaluation in Higher Education, 28, 471-488. doi:10.1080/0260293032000120352

Pupovac, V., Bilic-Zulle, L., \& Petrovecki, M. 2008. On academic plagiarism in Europe. An analytical approach based on four studies. Digithum, 10, 13-19.v.

Roig, M., \& Caso, M. 2005. Lying And Cheating: Fraudulent Excuse Making, Cheating, And Plagiarism. The Journal of Psychology, 139 (6), 485-494. 
Sattler, S., Graeff, P., \& Willen, S. 2013. Explaining the decision to plagiarize: An empirical test of the interplaybetween rationality, norms, and opportunity. Deviant Behavior, 34, 444-463. doi:10.1080/01639625.2012.735909

Sagoro, E. M. 2013. Pensinergian Mahasiswa, Dosen, dan Lembaga dalam Pencegahan Kecurangan Akademik Mahasiswa Akuntansi. Jurnal pendidikan akuntansi Indonesia, 11 (2).

Thomas, E. E \& Sassi, K. 2011. An ethical dilemma: talking about plagiarism and academic integrity in the digital age. English Journal, 100 (6), 47-53.

Thomas, D. 2017. Factors that explain academic dishonesty among University Students in Thailand. Ethics \& Behavior, 27(2), 140-154.

Teodorescu, D., \& Andrei, T. 2009. Faculty and peer influences on academic integrity: College cheating in Romania. Higher Education, 57, 267-282. doi:10.1007/s10734-008-9143-3

Trost, K. 2009. Psst, have you ever cheated? A study of academic dishonesty in Sweden. Assessment \& Evaluation inHigher Education, 34, 367-376. doi:10.1080/02602930801956067

Ungusari, E. 2015. Kejujuran dan Ketidakjujuran Akademik pada Siswa SMA yang Berbasis Agama. Skripsi (tidak diterbitkan). Fakultas psikologi, Universitas Muammadiyah Surakarta). Psikologi Universitas Muhammadiyah Surakarta

Vasconcelos, S., Leta, J., Costa, L., Pinto, A., \& Sorenson, M. 2009. Discussing Plagiarism In Latin America. EMBO Reports, 4, 677-682 Whitley, B. E. 1998. Factors Associated With Cheating Among College Students: A Review. Research in Higher Education, 39 (3), 235274. 